CHAPTER 15:

\title{
Reflections on the IEA Civic Education Study in the United States: Policies, People, and Research
}

\author{
Carole L. Hahn
}

\begin{abstract}
In this chapter, the national research coordinator for the United States (US) in IEA's 1999 Civic Education Study (CIVED) reflects on US participation in that study and its legacy, especially in light of the fact that the US did not participate in the later ICCS studies. She describes decisions related to the qualitative research methods used in Phase I of CIVED, as well as findings from it. The main findings from the quantitative Phase II of the study, which revealed US students' civic knowledge, attitudes, and experiences in 1999, are described. Policy documents, publications, and subsequent research in the US informed by findings from CIVED are discussed. There were extensive contributions to civic education research both nationally and internationally from scholars who participated in CIVED and by other scholars who have expanded research on themes identified in that study during the ensuing two decades.
\end{abstract}

\section{Introduction}

Preparing youth for their roles as citizens in a democracy has long been valued in the United States (US). From the early days of the Republic, through the growth of the nation, civic education was widely cited as a primary purpose of public schools. Civic education has been delivered through particular subjects, such as civics, history, and social studies, as well as across the curriculum through extra-curricular activities and school-wide practices, such as mock elections and patriotic celebrations. By the end of the 20th century, however, many stakeholders bemoaned declining attention to civic education (Carnegie Corporation of New York and Center for Information and Research on Civic Learning and Engagement [CIRCLE] 2003). The opportunity to participate in the Civic Education Study (CIVED) of the International Association for the Evaluation of Educational Achievement (IEA) came at a time in the mid-1990s when increasing numbers of educational leaders advocated shining a light on the subject and what they saw as its diminished status.

The US participated in the first IEA civic education study (Torney et al. 1975) and since the 1970s researchers had conducted numerous national assessments of students' civics, history, and social studies knowledge. However, in the mid-1990s no recent information was available on US students' civic knowledge, attitudes, and behaviors in comparison to students in other countries. CIVED provided an opportunity to obtain such information and to involve US civic educators in an international network and discourse on civic education cross-nationally. This chapter describes the US portion of the study and some of its key findings before reflecting on the subsequent legacy of the study in the US. Policy documents and publications that were informed by CIVED findings and that influenced discussions about policies and practices are discussed. The subsequent work of scholars who participated in the study and have continued to make important contributions to the field of civic education is considered along with the enlarging research base on civic education attributable to a growing number of early career scholars. The chapter's conclusion reflects on the contributions of CIVED to the ongoing discourse about civic education in the US and cross-nationally.

Carole L. Hahn, Emory University, Atlanta, Georgia, United States

email: chahn@emory.edu

(C) IEA International Association for the Evaluation of Educational Achievement 2021

B. Malak-Minkiewicz and J. Torney-Purta (eds.), Influences of the IEA Civic

and Citizenship Education Studies, https://doi.org/10.1007/978-3-030-71102-3_15 


\section{The Study and Key Findings}

As the national project representative for Phase I and national research coordinator for Phase II of CIVED in the US, I chaired the National Expert Panel and supervised the collection and analyses of data for Phase I; this included a survey of literature, a textbook analysis, focus group interviews with teachers and students, and surveys of the 50 state coordinators of social studies and representatives of 100 organizations working in the area of civic education in the US (Hahn 1999). For Phase II, I chaired the US CIVED Steering Committee, which advised the American Institutes of Research staff (under contract with the National Center of Education Statistics) on conducting, analyzing, and reporting on the quantitative portion of the study in the US (US Department of Education 2001). It also involved working with a team of doctoral students at Emory University and representing the US at meetings of the international research teams.

As background to CIVED, I had taught secondary school social studies before joining the faculty at Emory University in Atlanta, Georgia. I had been president of the National Council for the Social Studies (NCSS, the professional association of social studies educators). For a decade I had also been conducting comparative research on civic education in the US and in Denmark, England, Germany, and the Netherlands. That study was published as a book, Becoming Political: Comparative Perspectives on Citizenship Education (Hahn 1998). The book reviewed research on political socialization since the 1960s, paying particular attention to the measurement of political interest, political trust, political efficacy, and political confidence, as well as classroom climate for discussion and political tolerance. Surveys were administered to adolescents in approximately 50 schools in five countries in 1985-1986 and 1992-1993. Observations were made of classes, and teachers and students were interviewed. As this was not a representative sample, it was important not to generalize beyond the sample in each country. Nevertheless, the quantitative data did suggest that youth in the study who came from the same country shared some similarities with respect to the nature of their political attitudes, gender differences, and classroom climates for discussion. Qualitative data from observations and interviews provided insights to facilitate understanding of those trends. Importantly, across and within countries, when students had opportunities to discuss controversial issues, they reported higher levels of political interest and efficacy than did students without such experience. Detailed descriptions of how teachers in each country used country-specific approaches to enable students to explore and discuss social, political, and economic issues were included. From these data, it was clear there was no single preferred way of doing civic education, even in democratic countries that were quite similar.

At the first meeting of the international CIVED research team in July 1995 in Enschede, the Netherlands, it became very evident that civic and political education varied considerably across national contexts. The national coordinators came to the project meeting with widely differing political experiences that shaped what they expected to learn from their country's participation in a cross-national study. Models originating in the US or Western Europe were viewed with skepticism by some attendees. The design that was finally approved included a qualitative Phase I set of case studies that collected information about the current aims of civic education in each country in part to address these concerns. This required a broader set of competencies on the part of research staff than would have been the case if the study had been limited to collecting data through a test and survey.

In order to carry out Phase I of the study in the US, a team of Emory University doctoral students drew on experiences with both qualitative and quantitative research methods, including those mentioned above. It was clear that certain features of US education should be captured in the Phase I case study. For example, because education policy in the US is decentralized (to an extent that is unlike many other countries), it was important to survey the 50 state-level social studies coordinators or their equivalents (identified in the directory of the NCSS Council of State Social Studies Supervisors) and to conduct focus groups with teachers and students in different 
parts of the country. It was also important in selecting a sample of textbooks for analysis to take account of differing textbook adoption policies in different US states. Further, it was important to conduct a survey of the many organizations involved in US civic education nationally, regionally, or at the state level-a unique contextual factor.

The team presented our findings from Phase I to several US audiences of social studies specialists and wrote several publications, including the US case study for the international report (Hahn 1999). Students in the US tended to have similar experiences with the content of what they studied in civic education; however, these students had a variety of experiences with pedagogy (how civic education was taught). Most 14 to 15-year-old students learned about democracy, political institutions, and rights and responsibilities of citizens from lessons in US history and from civics courses in grade 8 or 9 . The content and sequence of topics varied little across textbooks for US history (organized chronologically) and civics (organized according to branches of government following the US Constitution). Most 14 to 15-year-olds learned about national identity and social cohesion in US history lessons, extra-curricular activities, and the wider society around them. Students in focus groups used the terms "we" and "our" in referring to the nation's past, even when their ancestors had not been in the country at the time. Textbooks depicted the country as "a nation of immigrants" and students reported studying about the oppression of Native Americans, immigration, women's history, slavery, segregation, and the Civil Rights Movement. Textbooks and students were less likely to mention Latinx and Asians, except in states where many individuals from those groups resided. These and other findings from Phase I provided context for understanding the results for Phase II and they have since been explored by other researchers in the US. However, several themes could not be explored directly in Phase Il because they were not cross-nationally meaningful.

If one compares the US chapter in the case study book (Hahn 1999) to the case studies from other countries, some findings are clearly similar. For example, students before age 14 acquired most of their civic knowledge from lessons in history and social studies rather than a specific course in civics or government (Hahn and Torney-Purta 1999). The US case study noted that although much of the professional literature recommended the exploration of issues and the use of reflective inquiry, there was not much evidence of either approach in the textbook analysis or the responses of educators in focus groups. Authors of many of the other national case studies made similar observations. Although there was a wide variation in the number of participatory civic activities that were offered to students in different schools, overall US schools tended to offer a substantial number of those activities. US students, like their peers in other countries, studied national history and they appeared to develop a sense of national identity (as indicated by the use of "our" and "we" as noted above when discussing historic events). US students learned about diverse racial and ethnic groups, immigrants, and women who had contributed to the nation's history. However, several scholars noted that more could be done in this area. Interestingly, after examining the Phase I case study volume, Hahn and Torney-Purta (1999) reflected that no chapter author claimed that their country had a fully successful multicultural education program.

In Phase II a nationally representative sample of 2,811 US grade 9 students were assessed in 1999 with the international instruments covering civic knowledge (including civic content and skills), concepts, attitudes, and experiences (US Department of Education 2001). An article published in the NCSS journal, Social Education, reported that the study yielded good and bad news (Hahn 2001). The good news was that overall, US students scored above the international mean on the test of civic knowledge-both content knowledge and skills. Further, students who reported studying social studies every day performed better on the civic knowledge test than their peers who studied social studies less frequently. The bad news was that students who attended schools with many students from low-income households, those with few literacy 
resources at home, and those whose parents had fewer years of schooling performed less well on the knowledge test than peers from higher income, more literacy-resourced homes, and with more educated parents. Further, white and multi-racial students tended to perform better on the knowledge test than did black and Hispanic students on average.

Additionally, there was good news that US students tended to support women's rights and immigrants' rights and half of the students reported that they had participated in a voluntary group that helps the community. Bad news related to the minority of students who did not support women's and immigrants' rights and the finding that fewer US students than students in most other countries reported following television news, particularly international news.

The CIVED reports at the national level (US Department of Education 2001) and international level (Torney-Purta et al. 2001) contained many other interesting insights. Unfortunately, however, journalists' coverage of the findings in the US was minimal. When the national report was released at an educational press conference, the US Secretary of Education chose not to speak about the national or the international civic test survey results; instead he gave a speech focusing on the Bush administration's new policy called No Child Left Behind. Consequently, reporters focused on what was wrong with US education in terms of mathematics and reading achievement. There was far less interest in what was right with US education-the good news in the CIVED reports. Not surprisingly, when plans were being made for ICCS 2009, the US Department of Education declined to participate citing other priorities. There was insufficient interest in using federal dollars to fund US participation, and nongovernmental organizations were not able to garner the needed financial and institutional support for participation in either 2009 or 2016. As a result, there are no recent data available on US students' civic knowledge in comparison to students in other countries.

Further, there is little information about US students' civic attitudes from nationally representative samples. Until recently the National Assessments of Educational Progress (NAEP) only assessed knowledge and skills, with the 2018 civics assessment giving some attention to "civic dispositions." For the most part, researchers and policymakers use recent attitudinal information from small, sometimes non-representative, samples as a basis for their suggestions and policies. Nevertheless, a substantial number of those interested in improving civic education continue to consider CIVED results as valuable, particularly because the sampled students provide insights into the attitudes prevalent among the generation of citizens who are now in their mid-30s.

\section{Contributions to Policy, Practice, and Discourse Available in Documents and Books}

Although it is not possible to make causal claims directly connecting CIVED's findings to policy reforms in the US, it is clear that findings from the study became and remain an important feature of discourse among policymakers, researchers, and practitioners. Authors of policy papers and widely-read books cited the study, members of the CIVED research team have been featured on panels at civic education conferences, and were invited to write numerous articles and chapters for edited volumes (e.g., Hahn 2002, Torney-Purta 2005).

Soon after the publication of the international and national CIVED reports, the Center for Information and Research on Civic Learning and Engagement (CIRCLE), was established with funding from the Carnegie Corporation of New York. This organization convened meetings of researchers and representatives of civic-focused organizations to develop a policy document calling for greater attention to civic education. Organizers and many of the participants in the meetings were familiar with the findings from CIVED and cited them in discussions. Statements referring to these findings can be found throughout the resulting report, The Civic Mission of Schools (Carnegie Corporation of New York and CIRCLE 2003). The initial report was reissued in a slightly edited version in 2011, with lessened emphasis on the research background, under 
the title Guardian of Democracy: The Civic Mission of Schools. These two reports were widely read and frequently cited as several states and school districts increased their requirements for courses in civics and/or government and some educators gave greater attention to discussions of current events in social studies classes.

Several other meetings culminated in the publication of further reports making recommendations for effective civic education. Experiences with and findings from CIVED contributed to the recommendations for policy and practice that were included in these reports (Anderson and Landman 2003; Banks et al. 2005; Malin et al. 2014; Torney-Purta and Richardson 2003).

In 2013, NCSS issued a new recommended framework for the social studies curriculum titled The College, Career, and Civic Life (C3) Framework for Social Studies State Standards (NCSS 2013). The C3 Framework, which is an aspirational and non-compulsory framework, addresses the four disciplines of civics, history, economics, and geography, emphasizing disciplinary concepts and use of inquiry. The outcome of student inquiry across disciplines is to be "communicating conclusions and taking informed action," thus highlighting the civic purpose of social studies. The framework, which has guided a great deal of social studies curriculum and instructional development in recent years, cites only one article from CIVED (Torney-Purta 2005). However, the framework incorporates a number of ideas gleaned from CIVED. The most prominent is the importance of classroom discussion and debate of current social problems to enhancing civic knowledge.

Further evidence of CIVED contributing to national discourse on civic education is found in several books. CIVED researchers identified two themes that subsequently became the focus of several studies. The first theme, inequality of civic opportunities and outcomes, was reinforced in research by Kahne and Middaugh (2008) and was the focus of the book No Citizen Left Behind by Levinson (2012). The second theme, the importance of controversial issues discussions and a "classroom climate" supportive of democratic discourse was reinforced and extended by Hess and McAvoy in two books, Controversy in the Classroom (Hess 2009) and The Political Classroom (Hess and McAvoy 2015). CIVED had provided important evidence from a nationally representative sample of students that students in schools with high poverty populations (often serving many students of color) tended to be at a disadvantage with respect to civic education and that a supportive classroom climate for discussion was associated with student knowledge and expectations of electoral engagement. The authors of these books added in depth qualitative evidence from US classrooms to show how teachers can overcome obstacles to provide high quality civic experiences for all students. These three books have been read by teachers and teacher-educators across the country and have done much to make these issues central in the discourse about social studies and civic education reform. In late 2019 the National Academy of Education obtained foundation funding to hold a meeting of researchers and prepare an extensive report on Educating for Civic Discourse and Reasoning. Several individuals who participated in CIVED or in secondary analysis of those data were part of that organizing group or prepared papers (Barber et al. 2021). The newest national report is Educating for American Democracy (2021).

\section{Building a Sense of Community Among CIVED Scholars}

Over the years in which CIVED national research coordinators (NRCs) met with the international planning committee to coordinate the study, the researchers learned much from one another about the diversity of civic education internationally, bonds were established, and friendships formed. NRCs exchanged information about research, publications, and issues and met informally at professional conferences, such as the American Educational Research Association, the Comparative and International Education Society, and CitizED (a network of scholars interested in civic education). When Australia launched a new civic education program, NRCs from the US, England, and Hong Kong were invited to speak at a conference in Canberra. Several NRCs 
were also invited to write chapters for edited volumes on civic education, some of which used CIVED data while others discussed the varied national contexts (Arthur et al. 2008; Wilde 2005).

As a result of cooperation among the NRCs from Australia, Hong Kong, and the US, an article was published in the Comparative Education Review, based on secondary analysis of the CIVED data for students from Australia, Hong Kong, and the US (Kennedy et al. 2008). We were concerned that when researchers compare item response theory scale means, as they did in the international report, this masked important distinctions between student samples in different sociocultural contexts. For that reason, this article compared percentages of student responses on scales and individual items and drew on research literature about civic culture and civic education in specific societies to understand similarities and differences in responses.

The article sought to explain, interpret, and bring meaning to the initial analysis using both insider and outsider perspectives. In other words, each author reflected on his or her own society's culture and history at the same time raising questions about contrasts and similarities seen in the other two societies. The focus was on scales concerned with citizenship (the conventional citizenship, social-movement citizenship, and expected future participation scales) and with rights (the women's rights and immigrants' rights scales). There was agreement among students in the three societies about which behaviors they considered most important to being a good citizen (voting, followed by showing respect for leaders and knowing the country's history), as well as behaviors they considered least important (joining political parties and following and discussing political affairs). However, upon reflection it became clear there are different reasons in the three countries. Across societies students also tended to support social or community engagement, rather than political engagement. Further, although regardless of country students gave priority to the same behaviors, there was considerable variation across societies in students' level of endorsement of particular actions, with US and Hong Kong students for the most part indicating support for higher levels of engagement than students in Australia. Those differences could be attributed to differing histories, civic cultures, and school instruction. Across societies, most students were supportive of rights for women and immigrants, although with differing intensity of support, again reflecting local histories, cultures, and instruction. Both local and global forces appeared to be important to understanding youth civic orientations, and other researchers should be encouraged to explore findings from international studies at this level of detail and in light of particular sociocultural and historic contexts.

Working with Hong Kong and Australian colleagues was an introduction to the diversity of civic education in the Asia Pacific Region through participation in conferences and writing for publications. Synthesizing articles placed CIVED in the context of other comparative and international research in civic education (Hahn 2010a, 2010b, 2016).

Since 2009, I have been studying civic education in northern Europe in a comparative qualitative study of schools serving many students of immigrant backgrounds in Denmark, Germany, the Netherlands, and the United Kingdom (Hahn 2015, 2017, 2020). This study builds on the earlier Becoming Political study (Hahn 1998), but focuses on migration and transnationalism, as over the past 20 years these countries have experienced increased migration and diversity as well as changes in civic education policies. These four countries participated in different IEA studies (CIVED, ICCS 2009, and ICCS 16), which assessed students' attitudes toward immigrants' rights and compared immigrant and non-immigrant students on a number of scales. However, those studies did not have parallel qualitative data, and this study was designed to investigate what civic education looks like in specific schools and how educators think about preparing citizens when their students' families come from many different countries. Distinct civic and pedagogical cultures, as well as differing histories of migration and diversity, influence civic education. The educators in this study identified many advantages and a few challenges in teaching citizenship to classes with many students of immigrant backgrounds. However, with a few exceptions, 
they tended to take into account their students' transnational knowledge, experiences, and attachments in quite limited ways.

The more I have learned about civic education cross-nationally, from CIVED and other studies, the more I have come to appreciate the important differences that reflect differing historic and socio-cultural contexts. It is important not to generalize findings from one country to another and for researchers to provide as much information as they can about the historical and sociocultural contexts of the countries from which their data are obtained. The formation of a network of comparative civic education scholars has resulted in researchers developing a deepened understanding of national and global citizenship.

However, National Research Coordinators are not the only CIVED scholars who have continued to extend civic education research. Several senior scholars were selected to be on the US National Expert Panel for Phase I and the US CIVED Steering Committee for Phase II because of their expertise in civic education, and several younger scholars began their careers as doctoral students working on the research team for the project. Both groups of individuals have continued to make contributions to civic education, social studies, and education broadly. Notably, Walter Parker, from the University of Washington, a member of the Expert Panel and Steering Committee, has extended his earlier work on diversity and democratic education, the importance of classroom discussion, and civic education curriculum development. In recent years he led a team to reform the curriculum for civics and government courses. His design-based research places simulations and experiential-based learning at the center of instruction (Parker 2018). Patricia Avery, from the University of Minnesota, was another senior scholar who brought considerable expertise to the US National Expert Panel and Steering Committee's work. Avery, and one of her doctoral students, Annette Simmons, conducted the textbook study for Phase I of CIVED in the US (Avery and Simmons 2001). Subsequently, Avery extended her earlier work on students' civic attitude development to a cross national study, supported by the Constitutional Rights Foundation that included nine central and eastern European countries (Levy et al. 2011).

Doctoral students on the Phase I team for CIVED in the US built on their work on the project for their dissertations. Extending her interest in the Phase I discussion of social cohesion and diversity, Paulette Dilworth conducted studies on multicultural citizenship education. In subsequent years, she wrote several publications on diversity and civic education (e.g., Dilworth 2008) and worked as a university administrator focusing on diversity issues. A second doctoral student, Trisha Sen, extended her work on the CIVED discussion of teaching that connects economic and political institutions to her dissertation study of such teaching in the US and India. She has continued to work on teacher development and educational reform in India.

\section{Extending Research Beyond CIVED}

In addition to the research conducted by the CIVED researchers cited above, the next generation of civic education scholars in the US has extended findings and methodologies from CIVED. Knowles et al. (2018) identified and summarized more than 100 studies that reported analyses of CIVED and ICCS 2009 data. In addition to re-examining the original data, numerous scholars have extended lines of inquiry established in the CIVED study. Theresa Alviar Martin, Ana Solano Campos, and Laura Quaynor used CIVED scales and concepts in their own studies examining civic attitudes in samples of immigrant and refugee students in Hong Kong, the US, and Costa Rica. In addition to Diana Hess' research described earlier, Li-Ching Ho, Thomas Misco, and Judith Pace have been researching controversial issues, discussions, and civic outcomes in different national contexts. Brett Levy (2019) has used multiple methods to improve the measurement of and explore the concepts of political efficacy, political interest, classroom climate, and schoollevel civic participation among US students. 
As noted earlier, research by Kahne and Middaugh, and Levinson extended the CIVED findings related to inequality. In addition, in recent years, many researchers in the US have used qualitative methods to explore a theme that emerged in Phase I of CIVED in the US: the varying civic experiences among youth of color (Castro and Knowles 2017). Further, as the internet and social media have become central features of civic and youth life in the years since CIVED, researchers are now exploring questions related to digital citizenship (Kahne et al. 2016) and "action civics" that extend earlier conceptions of civic behavior and active citizenship (Blevins et al. 2016).

Two organizations have been instrumental in expanding the research on civic education. CIRCLE, now based at Tufts University (originally established at the University of Maryland) conducts and supports research by others on youth civic engagement, using many different samples. Finally, in the decade since the Spencer Foundation launched its "New Civics" Initiative in 2008, they have funded more than 100 studies of civic education in the US and internationally. A Spencer Foundation grant supported the establishment of a project called CivicLEADS, at the University of Michigan (CivicLEADS.org). That project has curated and made freely available more than 20 data sets (with accompanying instruments and publication lists); this includes three IEA data sets (CIVED, ICCS 2009, ICCS 2016).

\section{Concluding Reflections}

Although it is not possible to draw a direct causal link between CIVED and changes in civic education policy and practices, it appears that over time the study did have considerable impact on enhancing recognition of the importance of civic education in the US. It is true federal officials and the media gave little attention to the release of the CIVED national and international reports. These officials did not agree to support participation in the subsequent IEA civic education studies. However, individuals who worked on the CIVED study were respected (and persistent) members of the social studies/civic education community, which enabled them to bring attention to this area of schooling. Findings from this study along with advocacy from many individuals and groups convinced many policymakers of the importance of deliberate civic education. Many states and school districts have increased their requirements for students taking civics or government before they can graduate from secondary school. Thanks to CIVED and other researchers, today there is widespread agreement among civic educators that an open classroom climate for discussion and participatory school civic experiences are important for civic knowledge and engagement. Whereas CIVED identified inequality as an important issue that needed addressing, civic education researchers of today are exploring the nuances and complexity of diverse identities, civic experiences, and civic outcomes.

CIVED confirmed that there was no longer a gender difference in civic knowledge in the US as had existed previously and that finding was later confirmed in national assessments. However, CIVED revealed quite a few gender differences in civic attitudes that have been only partially explored (Hahn and Quaynor 2012; Kennedy et al. 2008).

Researchers in the US are currently exploring other lines of inquiry that have become salient in recent years. In particular, they are investigating the role of digital and social media in civic learning and also ways in which increased political polarization in the country impacts youth. Unfortunately, they are not able to gain insights from an internationally comparative view on these issues because the officials in the US who are responsible for organizing and funding the international studies did not agree to participate in IEA's civic education studies after 1999. Many of us hope that the public and their representatives will soon swing back from a period of what appears to be isolationism and a narrow concern for mathematics and science achievement to recognize the need for placing US students' civic experiences in a global context and again join the community of international civic education scholars in future studies. 


\section{References}

Anderson, C. C., \& Landman, J. H. (2003). Globalization and border crossings: Examining issues of national identity, citizenship, and civic education. Chicago, IL: American Bar Association.

Avery, P. G., \& Simmons, A. M. (2001). Civic life as conveyed in US civics and history textbooks. International Journal of Social Education, 15 (Fall/Winter), 105-30.

Arthur, J., Davies, I., \& Hahn, C. (Eds.). (2008). The Sage handbook of education for citizenship and democracy. London, United Kingdom: Sage.

Banks, J. A., McGee Banks, C., Cortes, C. E., Hahn, C. L., Merryfield, M. M., Moodley, K. A., MurphyShigematsu, S., Osler, A., Park, C., \& Parker, W. C. (2005). Democracy and diversity: Principles and concepts for educating citizens in a global age. Seattle, WA: Center for Multicultural Education, University of Washington. Barber, C., Clark, C., \& Torney-Purta, J. (2021). Learning environments and school/classroom climate as supports for civic reasoning, discourse, and engagement. In C. Lee, G. White, \& D. Dong (Eds.), Educating for civic reasoning and discourse. Washington, DC: National Academy of Education.

Blevins, B., LeCompte, K., \& Wells, S. (2016). Innovations in civic education: Developing civic agency through action civics. Theory and Research in Social Education, 44, 344-384.

Carnegie Corporation of New York \& Center for Information and Research on Civic Learning and Engagement [CIRCLE]. (2003). The civic mission of schools. New York, NY: Author.

Castro, A.J., \& Knowles, R.T. (2017). Democratic citizenship education: Research across multiple landscapes and contexts. In M. M. Manfra, \& C. M. Bolick, (Eds.), The Wiley handbook of social studies research (pp. 287-318). West Sussex, United Kingdom: John Wiley \& Sons.

Dilworth, P. P. (2008). Multicultural citizenship education. In J. Arthur, I. Davies, \& C. Hahn (Eds.), The SAGE handbook of education for citizenship and democracy (pp. 424-437). London, United Kingdom: Sage. Educating for American Democracy. (2021). Excellence in history and civics for all learners. https:// www.educatingforamericandemocracy.org/wp-content/uploads/2021/02/Educating-for-AmericanDemocracy-Report-Excellence-in-History-and-Civics-for-All-Learners.pdf

Hahn, C. L. (1998). Becoming political: Comparative perspectives on citizenship education. Albany, NY: State University of New York Press.

Hahn, C. L. (1999). Challenges to civic education in the United States. In J. Torney-Purta, J. Schwille, \& J. A. Amadeo, Civic education across countries: Twenty four national case studies from the IEA civic education project (pp. 583-607). Amsterdam, the Netherlands: International Association for the Evaluation of Educational Achievement (IEA).

Hahn, C.L. (2001). Student views of democracy: The good and bad news. Social Education, 65, 456-460.

Hahn, C.L. (2002). Education for democratic citizenship: One nation's story. In W. Parker (Ed.), Education for democracy: Contexts, curricula, assessments (pp. 63-92). Greenwich, CT: Information Age Publishing.

Hahn, C. L. (2010a). Issues-centered pedagogy and classroom climate for discussion: A view from the United States. In K. J. Kennedy, W. O. Lee, \& D. L. Grossman, Citizenship pedagogies in Asia and the Pacific. Hong Kong: Comparative Education Research Centre, The University of Hong Kong.

Hahn, C.L. (2010b). Comparative civic education research: What we know and what we need to know. Citizenship Teaching \& Learning, 6(1), 5-23.

Hahn, C. L. (2015). Teachers' perceptions of education for democratic citizenship in schools with transnational youth: A comparative study in the UK and Denmark. Comparative \& International Education, 10(1), 95-119.

Hahn, C.L. (2016). Pedagogy in citizenship education research: A comparative perspective. Citizenship Teaching \& Learning, 11(2), 121-137.

Hahn, C. L. (2017). Social studies in Germany: A comparative view. In R. A. Diem, \& M. J. Berson, (Eds.), Mending walls: Historical, socio-political, economic, and geographical perspectives (pp. 1-16). Charlotte, NC: Information Age Publishing.

Hahn, C. L. (2018). From global education to comparative global citizenship education: One woman's journey. In T. F. Kirkwood-Tucker (Ed.), The global education movement (pp. 325-361). Charlotte, NC: Information Age Publishing.

Hahn, C. L. (2020). Educating citizens in an age of globalization, migration, and transnationalism: A comparative study in four European democracies. Theory and Research in Social Education, 48, 244-284.

Hahn, C.L., \& Quaynor, L. (2012). Gender and civic education. In J.A. Banks (Ed.), Encyclopedia of diversity in education (pp. 942-950). New York, NY: Sage. 
Hahn, C. L., \& Torney-Purta, J. (1999). The IEA civic education project: National and international perspectives. Social Education, 65(7), 425-431.

Hess, D. E. (2009). Controversy in the classroom: The democratic power of discussion. New York, NY: Routledge.

Hess, D. E., \& McAvoy, P. (2015). The political classroom: Evidence and ethics in democratic education. New York, NY: Routledge.

Kahne, J., Hodgin, E., \& Eidman-Aadahl, A. (2016). Redesigning civic education for the digital age: Participatory politics and the pursuit of democratic engagement. Theory and Research in Social Education, 44, 1-35.

Kahne, J., \& Middaugh, E. (2008). Democracy for some: The civic opportunity gap in high school. Working Paper 59. College Park, MD: Center for Information \& Research on Civic Learning and Engagement.

Kennedy, K. J., Hahn, C. L., \& Lee, W. O. (2008). Constructing citizenship: Comparing the views of students in Australia, Hong Kong, and the United States. Comparative Education Review, 52, 53-91.

Knowles, R., Torney-Purta, J., \& Barber, C. (2018). Enhancing citizenship learning with international comparative research: Analyses of IEA civic education datasets. Citizenship Teaching \& Learning, 13(3), 7-30. Levinson, M. (2012). No citizen left behind. Cambridge, MA: Harvard University Press.

Levy, B. (2019). Motivating political participation among youth: An analysis of factors related to political participation and engagement. Political Psychology, 40(5), 1039-55.

Levy, S. A., Avery, P.G., \& Simmons, A. M. (2011). Constructions of national narratives in established and emerging democracies based on student survey responses. Citizenship Teaching \& Learning, 7(1), 5-34.

Malin, H., Ballard, P., Attai, M., Colby, A., \& Damon, W. (2014). Youth civic development \& education: A conference consensus report. Stanford, CA: Center on Adolescence, Stanford University.

National Council for the Social Studies. (2013). Social studies for the next generation: Purposes, practices, and implications of the College, career, and civic life (C3) framework for social studies state standards. Silver Spring, MD: Author.

Parker, W. C. (2018). Projects as the spine of a course: designs for deeper learning. Social Education, 82(1), 45-48.

Torney, J.V., Oppenheim, A.N., \& Farnen, R.F. (1975). Civic education in ten countries. New York, NY: John Wiley and Sons.

Torney-Purta, J. (2005) The school's role in developing civic engagement: A study of adolescents in 28 countries. Applied Developmental Science, 6, 203-212.

Torney-Purta, J., Lehmann, R., Oswald, H., \& Schulz, W. (2001). Citizenship and education in twenty-eight countries: Civic knowledge and engagement at age fourteen. Amsterdam, the Netherlands: International Association for the Evaluation of Educational Achievement (IEA).

Torney-Purta, J., \& Richardson, W. (2003). Teaching for meaningful practice of democratic citizenship. Learning from the IEA Civic Education Study in 28 countries. In J. Patrick (Ed.), Principles and practices of democracy in the education of social studies teachers (pp. 25-44). Bloomington, IN: ERIC Clearinghouse for Social Science Education.

US Department of Education, National Center for Education Statistics. (2001). What democracy means to ninth graders: U.S. results from the international IEA Civic Education Study. NCES 2001-096, by S. Baldi, M. Perie, D. Skidmore, E. Greenberg, and C. Hahn. Washington, DC: Author.

Wilde, S. (Ed.). (2005). Political and citizenship education: International perspectives. Oxford Studies in Comparative Education. Oxford, United Kingdom: Symposium Books.

Open Access This chapter is licensed under the terms of the Creative Commons Attribution-NonCommercial 4.0 International License (http://creativecommons.org/licenses/by-nc/4.0/), which permits any noncommercial use, sharing, adaptation, distribution and reproduction in any medium or format, as long as you give appropriate credit to the original author(s) and the source, provide a link to the Creative Commons license and indicate if changes were made.

The images or other third party material in this chapter are included in the chapter's Creative Commons license, unless indicated otherwise in a credit line to the material. If material is not included in the chapter's Creative Commons license and your intended use is not permitted by statutory regulation or exceeds the permitted use, you will need to obtain permission directly from the copyright holder. 